\title{
Response of key stress-related genes of the seagrass Posidonia oceanica in the vicinity of submarine volcanic vents
}

\author{
C. Lauritano ${ }^{1}$, M. Ruocco ${ }^{2}$, E. Dattolo ${ }^{1}$, M. C. Buia ${ }^{1}$, J. Silva ${ }^{2}$, R. Santos ${ }^{2}$, I. Olivé ${ }^{2}$, M. M. Costa ${ }^{2}$, and G. Procaccini ${ }^{1}$ \\ ${ }^{1}$ Stazione Zoologica Anton Dohrn, Villa Comunale, 80121, Napoli, Italy \\ ${ }^{2}$ ALGAE-Marine Plant Ecology, CCMar - Centre of Marine Sciences, University of Algarve, Campus of Gambelas, \\ 8005-139 Faro, Portugal
}

Correspondence to: G. Procaccini (gpro@szn.it)

Received: 13 January 2015 - Published in Biogeosciences Discuss.: 30 March 2015

Accepted: 15 June 2015 - Published: 15 July 2015

\begin{abstract}
Submarine volcanic vents are being used as natural laboratories to assess the effects of increased ocean acidity and carbon dioxide $\left(\mathrm{CO}_{2}\right)$ concentration on marine organisms and communities. However, in the vicinity of volcanic vents other factors in addition to $\mathrm{CO}_{2}$, which is the main gaseous component of the emissions, may directly or indirectly confound the biota responses to high $\mathrm{CO}_{2}$. Here we used for the first time the expression of antioxidant and stress-related genes of the seagrass Posidonia oceanica to assess the stress levels of the species. Our hypothesis is that unknown factors are causing metabolic stress that may confound the putative effects attributed to $\mathrm{CO}_{2}$ enrichment only. We analyzed the expression of 35 antioxidant and stressrelated genes of $P$. oceanica in the vicinity of submerged volcanic vents located in the islands of Ischia and Panarea, Italy, and compared them with those from control sites away from the influence of vents. Reverse-transcription quantitative polymerase chain reaction (RT-qPCR) was used to characterize gene expression patterns.

Fifty-one percent of genes analyzed showed significant expression changes. Metal detoxification genes were mostly down-regulated in relation to controls at both Ischia and Panarea, indicating that $P$. oceanica does not increase the synthesis of heavy metal detoxification proteins in response to the environmental conditions present at the two vents. The up-regulation of genes involved in the free radical detoxification response (e.g., CAPX, SODCP and GR) indicates that, in contrast with Ischia, $P$. oceanica at the Panarea site faces stressors that result in the production of reactive oxygen species, triggering antioxidant responses. In addition, heat shock proteins were also activated at Panarea and
\end{abstract}

not at Ischia. These proteins are activated to adjust stressaccumulated misfolded proteins and prevent their aggregation as a response to some stressors, not necessarily high temperature.

This is the first study analyzing the expression of target genes in marine plants living near natural $\mathrm{CO}_{2}$ vents. Our results call for contention to the general claim of seagrasses as "winners" in a high- $\mathrm{CO}_{2}$ world, based on observations near volcanic vents. Careful consideration of factors that are at play in natural vents sites other than $\mathrm{CO}_{2}$ and acidification is required. This study also constitutes a first step for using stress-related genes as indicators of environmental pressures in a changing ocean.

\section{Introduction}

Seagrass meadows rank amongst the most valuable ecosystems to society in terms of the flow of services and values they support (Costanza et al., 1997; Seitz et al., 2014). They form multidimensional habitats for organisms directly participating in the trophic dynamics (Mazzella et al., 1992) and are a primary food source for herbivores on coral reefs, lagoons, and other shallow habitats (Orth et al., 2006). Seagrasses reduce sediment resuspension and their roots enhance sediment accretion, thus maintaining high water quality. Seagrass ecosystems also represent key sites for carbon storage in the biosphere and are important as $\mathrm{CO}_{2}$ sinks (Mcleod et al., 2011; Fourqurean et al., 2012; Pendleton et al., 2012; Pergent et al., 2012). 
There is consensus that increased $\mathrm{CO}_{2}$ will not have negative effects on seagrasses, which have even been predicted to extend their distribution, locally replacing macroalgae (Harley et al., 2006). Nevertheless, there may be indirect effects on seagrasses associated with increased $\mathrm{CO}_{2}$, as loss of phenolic protective substances due to lowered $\mathrm{pH}$ (Arnold et al., 2012) and light stress effects due to the modifications in the production and biomass of epiphytic algae on seagrass leaves. Regarding epiphytes, opposing light stress effects may be expected: shading, if non-calcifying epiphytes respond positively to increased $\mathrm{CO}_{2}$ (Martínez-Crego et al., 2014), or high light exposure, if calcifying epiphytes decline (Martin et al., 2008). Experimental evidence for increased seagrass productivity as a response to elevated $\mathrm{CO}_{2}$ levels is also inconclusive, and a recent meta-analysis did not detect significant effects of ocean acidification on seagrass photosynthesis (Kroeker et al., 2010). In a short-term experiment, the seagrass Zostera marina was found to grow at increasing rates under $\mathrm{CO}_{2}$ enrichment (Thom, 1996). Similarly, Jiang et al. (2010) found an increase in Thalassia hemprichii photosynthesis and leaf growth rate. Nonstructural carbohydrates increased in belowground tissues, whereas in aboveground tissues the carbon content was not affected by $\mathrm{CO}_{2}$ treatments. On the other hand, in a long-term experiment, there was no effect of increasing $\mathrm{CO}_{2}$ levels on the aboveground productivity of Zostera marina (Palacios and Zimmerman, 2007), as opposed to belowground. Alexandre et al. (2012) showed that the net photosynthetic rate of Zostera noltii was positively affected by the $\mathrm{CO}_{2}$ enrichment of the seawater, but they did not observe an increase in leaf growth rates.

A problem with the above experimental approaches is that even the longest experiments do not allow enough time for marine plants to adapt to high $\mathrm{CO}_{2}$ conditions thus making it difficult to forecast how they will perform in a future high $\mathrm{CO}_{2}$ ocean. This is the main argument to use submarine volcanic vents as natural laboratories for the effects of $\mathrm{CO}_{2}$ as this gas is the main component of emissions and the emissions have been happening for a long time (years to hundreds of years; Hall-Spencer et al., 2008).

In the last decade, gene expression approaches have been frequently used to assess the responses of marine organisms to ocean acidification (e.g., sea urchins (Evans et al., 2013; Evans and Watson-Wynn, 2014), corals (Kaniewska et al., 2012; Moya et al., 2012; Moya et al., 2015) and crustaceans (Harms et al., 2014)) both in field or controlled/mesocosm conditions. Research into natural gene expression variations within species in response to environmental changes is growing (Granados-Cifuentes et al., 2013; Oleksiak et al., 2002) due to its central role in the evolutionary adaptation processes which act at population and at species level (Whitehead, 2006).

A highly promising approach is to investigate the expression of specific genes involved in the response to stress (Granados-Cifuentes et al., 2013; Oleksiak et al., 2002;
Whitehead and Crawford, 2006). This approach will provide insight for understanding how marine organisms maintain or re-establish homeostatic metabolism in the face of varying physical or chemical environmental variables (Ahuja et al., 2010). Organisms react to environmental pressure by activating a series of conserved stress enzymes/proteins, including redox sensors (e.g., reactive oxygen species (ROS) sensors, antioxidants and detoxification systems), macromolecule damage sensors (e.g., stress-inducible heat shock proteins - HSPs) and/or condition-specific proteins that help to adjust the cellular physiology and metabolism protecting against cell damage or death.

Here we analyzed the expression levels of selected genes of the seagrass Posidonia oceanica in the vicinity of submerged volcanic vents located at the islands of Ischia and Panarea (Italy), and compared them with those from control sites away from the influence of the vents. Reversetranscription quantitative polymerase chain reaction (RTqPCR) was used to characterize expression levels of genes involved in stress responses, antioxidant activity, metalrelated responses and defense processes in $P$. oceanica in order to understand whether stress defense mechanisms are activated in the vicinity of submarine volcanic vents. Our hypothesis is that unknown factors are causing metabolic stress in $P$. oceanica in the vicinity of natural $\mathrm{CO}_{2}$ vents, which may confound the putative effects attributed to $\mathrm{CO}_{2}$ enrichment only.

In our analysis, target genes have been selected to include possible mechanisms that $P$. oceanica may activate in face of abiotic stressors (Mittler, 2006). We selected heat shock proteins (HSPs), genes from the primary metabolism (the first and second line of defense), antioxidants and other stressrelated enzymes. HSPs are molecular chaperones that can be involved in protein folding/unfolding, and degradation of misfolded or aggregated proteins (Sorensen et al., 2003). They are activated in response to various environmental stress factors (e.g., heat, hypoxia, UV radiation, $\mathrm{CO}_{2}$ enrichment, chemical exposure; Feder and Hofmann, 1999; Lauritano et al., 2015; Sorensen et al., 2003). From the first line of defense we analyzed a multixenobiotic resistance transporter or ATP-binding cassette protein (MXR/ABC), which is involved in the efflux of a large number of structurally and functionally diverse, moderately hydrophobic compounds, including anthropogenic pollutants and natural toxins (Bard, 2000). The second line of defense is characterized by detoxification reactions, such as oxidation, reduction, hydrolysis, hydration and de-halogenation of compounds to detoxify (e.g., cytochrome P450, or CYP450; Regoli and Giuliani, 2014). The second line of defense also includes aldehyde dehydrogenases (ALDHs) that detoxify a wide variety of endogenously produced and exogenous aldehydes catalyzing their oxidation to the corresponding acids (Marchitti et al., 2008). Reactive oxygen intermediates (ROIs), such as the superoxide anion, hydrogen peroxide and the hydroxyl radical, are intermediates of many physiological enzymatic reactions 
(e.g., mitochondrial respiration and redox enzymes, such as uncoupled nitric oxide synthase, cytochrome P450 isoforms, Lubos et al., 2011). They function as a signal for the activation of stress responses and are rapidly converted to less reactive forms. They are produced in higher amounts under stress conditions, such as drought stress, desiccation, heat shock, heavy metals, air pollutants, nutrient deprivation, mechanical stress and high light stress (Mittler, 2002). The accumulation of high quantities of ROIs can be very damaging to DNA, RNA and proteins and may activate programmed cell death (PDC). The free radical detoxification enzymes catalase (CAT), superoxide dismutase (SOD), glutathione peroxidase (GPX), ascorbate peroxidase (APX) and scavenger molecules such as glutathione were analyzed here.

The over-accumulation of ROIs when antioxidant/defense systems are not able to cope with stress may induce lipid peroxidation and PDC (Mittler, 2002). This is the reason why we also analyzed the expression of a lipoxygenase (LPX) involved in lipid peroxidation and a death-specific protein (DSP5) involved in cell death (Bidle and Bender, 2008). Other enzymes analyzed here have also antioxidant/protective properties. This is the case of Peroxiredoxin $\mathrm{Q}$, involved in free radical detoxification processes, and germin-like proteins, involved in many different processes such as metal stress response, fungal attack, osmotic regulation, cell wall restructuring and superoxide dismutase activities (Carter and Thombur, 1999; Lamkemeyer et al., 2006). In addition, other proteins/enzymes have been selected for their involvement in heavy metal responses/detoxification (Hussain et al., 2004; Ricachenevsky et al., 2013).

$P$. oceanica is endemic to the Mediterranean, providing a fundamental structural role and key ecological services (Cullen-Unsworth et al., 2014). It is therefore essential to understand which kinds of stresses the species are susceptible to and how it responds to them. This is the first study analyzing key protein activation in this species representing the first step for using stress-related genes of seagrasses as indicators of environmental pressures in a changing ocean.

\section{Methods}

\subsection{Sampling}

The study has been performed in the vicinity of submarine volcanic vents at the islands of Ischia and Panarea, Tyrrhenian Sea, Italy. In both cases, the hydrothermal vents are characterized by the emission into sea water of thermal waters and gases, mainly $\mathrm{CO}_{2}$, inducing changes in the chemical composition of the water column and associated community (Italiano and Nuccio, 1991; Kerrison et al., 2011).

Ischia: The study was performed in a very small fringe of a Posidonia oceanica meadow close to vent areas off the Castello Aragonese isle (Ischia; 40 43.849 ${ }^{\prime} \mathrm{N}, 13^{\circ} 57.089^{\prime} \mathrm{E}$; Naples, Italy). At this site, underwater $\mathrm{CO}_{2}$ vents occur in the shallowest rocky bottoms, and a pH gradient is formed (HallSpencer et al., 2008). Archaeological evidence suggests that vent sites around Castello Aragonese in Ischia were above sea level in the fourth century $\mathrm{BC}$, but that the region underwent a tectonic lowering (bradyseism) and was flooded by about AD 130-150 (de Alteriis and Toscano, 2003; Zucco, 2003). Thus, at these sites, subsurface vent activity can be dated back to about 1800-1900 years (Lombardi et al., 2011). Three individual shoots of $P$. oceanica were randomly collected at a control site at ambient $\mathrm{pH}$ in Ischia ( $\mathrm{S} 1$, about $8.14 \mathrm{pH})$ and at a site of low $\mathrm{pH}(\mathrm{S} 2$, about $7.83 \mathrm{pH})$ in dense and continuous meadows. Three additional shoots were collected from a very isolated and confined site (about $10 \mathrm{~m}^{2}$ ) of $P$. oceanica in conditions of extremely low $\mathrm{pH}$ (S3, about $6.57 \mathrm{pH})$. The depth range varies from 3.5 to $1 \mathrm{~m}$ along the $\mathrm{pH}$ gradient.

Panarea: The $\mathrm{CO}_{2}$ vents of Panarea originated from recent volcanic activity that occurred in 2002, which resulted in a series of gas bursts (Tassi et al., 2009). Sampling was conducted at two separate sites off the Island $\left(38^{\circ} 38^{\prime} 00^{\prime \prime} \mathrm{N}\right.$, $15^{\circ} 04^{\prime} 00^{\prime \prime} \mathrm{E}$ ) - a control site with pH 8.17 (the islet of Bottaro) and a relatively acidified site with $\mathrm{pH} 7.91$ (Formiche shoals), both at $12 \mathrm{~m}$ depth. At each sampling site, six adult shoots of $P$. oceanica were collected.

For both sites, tissue from the youngest fully mature leaves of the shoots (usually the second-rank leaf) was collected and rapidly cleaned from epiphytes with a razor blade, toweldried and immediately stored in RNAlater ${ }^{\circledR}$ tissue collection solution (Ambion, Life Technologies). Samples were then transported to the laboratory, preserved one night at $4{ }^{\circ} \mathrm{C}$ and stored at $-20^{\circ} \mathrm{C}$ until RNA extraction.

\subsection{Sample genotyping}

Samples collected for RT-qPCR analysis were also genotyped using species-specific microsatellite markers. About $50-70 \mathrm{mg}$ of dried tissue from individual samples was ground in a Mixer Mill MM300 (Qiagen). Subsequent DNA extraction was carried out using the NucleoSpin ${ }^{\circledR} 96$ Plant II kit (Macherey-Nagel) as in Tomasello et al. (2009). Individual multilocus genotypes were assessed by a total of 29 microsatellites (SSRs): 13 P. oceanica-specific anonymous loci that are putatively neutral and widely employed to assess neutral genetic variation (e.g., Procaccini and Waycott, 1998; Alberto et al., 2003; Migliaccio et al., 2005; Serra et al., 2010) and 16 loci representing a subset of the new ESTlinked microsatellites developed from two existing $P$. oceanica EST libraries (Arranz et al., 2013). PCR conditions were designed based on Arranz et al. (2013). Multiplex amplification reactions were performed using multiplex PCR buffer (Qiagen Multiplex PCR Master Mix).

PCR products were analyzed on an automated capillary electrophoresis sequencer (3730 DNA analyzer, Applied Biosystems). Electropherogram profiles were visualized and analyzed using the software PeakScanner (Applied Biosys- 
tems). Individual multilocus genotypes were determined using the software Gimlet (Valière, 2002).

\subsection{RNA extraction and cDNA synthesis}

Portions of seagrass leaf tissue were ground into a fine powder using a mortar and pestle and liquid nitrogen. About $100 \mathrm{mg}$ of powered tissue was used for the RNA extraction using an Aurum ${ }^{\mathrm{TM}}$ Total RNA Mini Kit (BIO-RAD) as in Mazzuca et al. (2013). After lysis solution, samples were homogenized using a Qiagen TissueLyser and tungsten carbide beads ( $3 \mathrm{~mm}$ ) (Qiagen) for $3 \mathrm{~min}$ at $20.1 \mathrm{~Hz}$. RNA quantity was assured by a NanoDrop ND-1000 UV-visible spectrophotometer (NanoDrop Technologies), monitoring the absorbance at $260 \mathrm{~nm}$; purity was determined by monitoring the $260 / 280 \mathrm{~nm}$ and $260 / 230 \mathrm{~nm}$ ratios using the same instrument. Both ratios were about 2.0. All samples were free of protein and organic solvents used during RNA extraction. RNA quality was evaluated by agarose gel electrophoresis that showed intact RNA, with sharp ribosomal bands. Total RNA (500 ng) was retro-transcribed into cDNA with the iScript $^{\mathrm{TM}}$ cDNA synthesis kit (BIO-RAD) following the standard protocol, using the GeneAmp PCR System 9700 (Perkin Elmer). The reaction was carried out in $20 \mu \mathrm{L}$ final volume with $4 \mu \mathrm{L} 5 \times$ iScript reaction mix, $1 \mu \mathrm{L}$ iScript reverse transcriptase and DNase-free $\mathrm{H}_{2} \mathrm{O}$. The mix was first incubated for $5 \mathrm{~min}$ at $25^{\circ} \mathrm{C}$, followed by $30 \mathrm{~min}$ at $42^{\circ} \mathrm{C}$ and finally heated to $85^{\circ} \mathrm{C}$ for $5 \mathrm{~min}$.

\subsection{Oligo design and PCR (polymerase chain reaction) optimization}

Primers for genes of interest (GOI) were designed considering sequences from the seagrass EST database Dr. Zompo (Wissler et al., 2009), unpublished sequences from the transcriptome of $P$. oceanica (D'Esposito et al., 2015) or from the generic online database GenBank (http://www.ncbi.nlm. nih.gov/genbank/; Table 2). Primers were designed using the software Primer3 v0.4.0 (http://frodo.wi.mit.edu/primer3/). Table 1 lists selected GOI, their functions, primers' sequences and amplicon sizes. Primers were optimized as in Serra et al. (2012). The sequences are deposited in GenBank under the accession numbers shown in Table 1.

\subsection{Best reference gene (RG) assessment}

In order to analyze the expression levels of specific GOI, a panel of seven putative reference genes (RGs) was first screened to find the most stable genes in the seagrass $P$. oceanica at both natural $\mathrm{CO}_{2}$-enriched sampling sites. The screened panel included the eukaryotic initiation factor-4A (eIF4A) (F 5'-TTCTGCAAGGGTCTTGACGT-3' and R 5'-TCACACCCAAGTAGTCACCAAG-3'; $E=1.85$; $\left.R^{2}=0.99\right)$ as well as the ones already published in Serra et al. (2012): ubiquitin (UBI), ribosomal protein L23 (L23), elongation factor 1-alpha (EF1A), glyceraldehyde 3- phosphate dehydrogenase (GAPDH), ribosomal RNA 18S (18S) and ubiquitin-conjugating enzyme (NTUBC2). Three different algorithms were utilized to identify the best RGs in our experimental design: BestKeeper (Pfaffl et al., 2004), geNorm (Vandesompele et al., 2002) and NormFinder (Andersen et al., 2004).

\subsection{Reverse-transcription quantitative polymerase chain reaction (RT-qPCR)}

Expression level analyses were then performed for specific GOIs related to antioxidant activity, stress and detoxification processes (Table 1 and Table 1S). Primer efficiencies were calculated for each oligo pair generating standard curves with five dilution points by using the cycle threshold $(\mathrm{Ct})$ value versus the logarithm of each dilution factor and using the equation $E=10^{-1 / \text { slope }}$. RT-qPCR was performed as in Dattolo et al. (2014). Control sites (S1 pH 8.14 and 8.17, for Ischia and Panarea, respectively) were used as reference conditions. Statistical analyses were performed using the statistical software Prism v4.00 (GraphPad Software). Statistical significant gene regulation was considered at $p<0.05$.

\section{Results}

\subsection{Best reference gene (RG) assessment for Ischia and Panarea}

According to the mathematical approach of BestKeeper, the most stable genes were L23, GAPDH and UBI for Ischia and 18S, L23 and UBI for Panarea (Figs. S1a and S2a in the Supplement). NormFinder indicated elF4a, NTUBC2 and UBI for Ischia and L23, NTUBC2 and EF1A for Panarea as best candidate reference genes (Figs. S1b and S2b in the Supplement). According to geNorm analysis, the two most stable genes were eIF4A and NTUBC2 in Ischia (Fig. S1c in the Supplement) and L23 and UBI in Panarea (Fig. S2c in the Supplement). All these genes were below the threshold M value of 1.5, which indicates that a gene can be considered suitable as a RG (Figs. S1c and S2c in the Supplement). The approach implemented in geNorm also allowed inferring the minimum number of necessary genes to be used as RGs in given data set. Pair-wise variation values were always $<0.15$ at both sampling sites ( $V$ value; Figs. S1d and S2d in the Supplement), indicating that only two genes were sufficient for the analysis. Nevertheless, when results were not consistent among the different approaches utilized, we also included a third RG in the analysis. The best RGs identified for each statistical approach and utilized for normalizing GOI expression levels at the two sampling sites were L23, elF4a and NTUBC2 in Ischia and L23, 18S and UBI in Panarea (Table 2). 
Table 1. List of selected genes of interest, with their abbreviations and functions.

\begin{tabular}{|c|c|c|}
\hline Abbreviation & Gene name & Function \\
\hline HSP90 & HSP90 & Stress protein \\
\hline DNAJ & Chaperone protein DNAJ & Stress protein \\
\hline HSP83 & HSP83 & Stress protein \\
\hline OzSP & Ozone stress protein & Stress protein \\
\hline DehSP & Dehydra stress protein & Stress protein \\
\hline SHSP & SH stress protein & Stress protein \\
\hline HSFA5 & Heat shock factor A5 & Heat shock protein transcription factor \\
\hline LBP & Luminal binding protein LBP & Stress protein \\
\hline $\mathrm{ABC}$ & ABC_MDH & Transporter protein \\
\hline CYP & Cytochrome P450 & Primary metabolism/detoxification \\
\hline ALDH & Aldehyde dehydrogenase & Primary metabolism/detoxification \\
\hline CAT & Catalase & Free radical detoxification \\
\hline SODCP & Superoxide dismutase $[\mathrm{Cu}-\mathrm{Zn}]$, chloroplastic & Free radical detoxification \\
\hline CSD1 & $\mathrm{Cu}-\mathrm{Zn}$ superoxide dismutase, cytosolic & Free radical detoxification \\
\hline FSD & Chloroplast iron superoxide dismutase & Free radical detoxification \\
\hline MSD & Manganese superoxide dismutase & Free radical detoxification \\
\hline GST & Glutathione S-transferase & Antioxidants \\
\hline GPX & Glutathione peroxidase & Antioxidants \\
\hline GSH-S & Glutathione synthase & Antioxidants \\
\hline GR & Glutathione reductase & Antioxidants \\
\hline AR & Ascorbate reductase & Antioxidants \\
\hline APX & Ascorbate peroxidase, microsomal & Antioxidants \\
\hline CAPX & Ascorbate peroxidase, chloroplastic (stromal) & Antioxidants \\
\hline Prx Q & Peroxiredoxin Q & Antioxidants \\
\hline GLP & Germin-like protein & Antioxidants \\
\hline DSP5 & Death-specific protein 5 & Apoptosis \\
\hline LPX & Lipooxygenase & Lipid metabolism \\
\hline $\mathrm{FtsH} 2$ & ATP-dependent zinc metalloprotease & Metal-related gene \\
\hline HMA & Heavy metal transport detoxification domain & Heavy metal domain \\
\hline NRAMP1 & Root-specific metal transporter & Heavy metal transporter \\
\hline HMATPase & Heavy metal p-type ATPase & Heavy metal ATPase \\
\hline HMATPase 5 & Heavy metal ATPase 5 protein gene & Heavy metal ATPase \\
\hline MT3 & Metallothionein-3 & Heavy metal stress response \\
\hline $\mathrm{Fe}-\mathrm{SP}$ & Iron-stress-related protein & Heavy metal stress response \\
\hline MTP & Metal tolerance protein & Heavy-metal-related gene \\
\hline
\end{tabular}

\subsection{Reverse-transcription quantitative polymerase chain reaction (RT-qPCR)}

P. oceanica samples collected for gene expression analyses were previously genotyped using microsatellite markers, assuring that there were at least three distinct genotypes for each gene expression replicate. Results obtained from all distinct genotypes, using the site with normal $\mathrm{pH}$ as control, show that a different gene category or specific gene functions have different behavior at the two sampling sites.

Opposite patterns of expression levels between the two sites were observed for many HSPs (Fig. 1a). At Ischia, many HSPs were significantly down-regulated. In particular, HSP90, HSP83 and the transcription factor HSFA5 were 2 -fold down-regulated at both site S2 and S3 $(p<0.001)$, while DNAJ was significantly down-regulated only at S3 $(p<0.001)$. However, HSP83 $(p<0.05)$ and DehSP $(p<0.01)$ were significantly up-regulated at the Panarea site (Fig. 1a). The other HSPs did not show significant changes.

For the primary metabolism genes, ABC and CYP were significantly up-regulated at the Panarea site $(p<0.01$ for both), while CYP was down-regulated only at the Ischia S2 site $(p<0.01)$. ABC did not show significant expression level changes in Ischia, and ALDH did not show significants changes at both Ischia and Panarea (Fig. 1b).

Regarding genes involved in the antioxidant response (Fig. 2a), CAT did not show significant changes in either Ischia or Panarea, while among the SOD isoforms analyzed (SODCP, CSD1, FSD and MSD), only the $\mathrm{Cu}-\mathrm{Zn}$ chloroplastic one (SODCP) was down-regulated at the Ischia S3 site $(p<0.001)$ and up-regulated at Panarea $(p<0.01)$. For the glutathione-related enzymes (GST, GPX, GSH-S and GR), GST was significantly down-regulated only at the Ischia S3 site $(p<0.001)$, GPX was up-regulated at all sites 
Table 2. Best reference genes as given by BestKeeper, NormFinder and geNorm analyses, for each sampling location (Ischia and Panarea). Genes are ranked from the most stable (in bold) to the least stable.

\begin{tabular}{clll}
\hline Rank & BestKeeper & NormFinder & geNorm \\
\hline Ischia (S2 and S3) & & \\
\hline 1 & L23 & elF4a & elF4a-NTUBC2 \\
2 & GAPDH & NTUBC2 & UBI \\
3 & UBI/elF4a/NTUBC2 & EF1A & EF1A \\
4 & EF1A & UBI & GAPDH \\
5 & $18 S$ & L23 & L23 \\
6 & & GAPDH & $18 S$ \\
7 & & 18S & \\
\hline Panarea & & & \\
\hline 1 & $\mathbf{1 8 S}$ & L23 & L23/UBI \\
2 & L23 & NTUBC2 & NTUBC2 \\
3 & UBI/NTUBC2 & EF1A/UBI & 18S \\
4 & elF4A & 18S & EF1A \\
5 & GAPDH & elF4A & elF4A \\
6 & EF1A & GAPDH & GAPDH \\
\hline
\end{tabular}

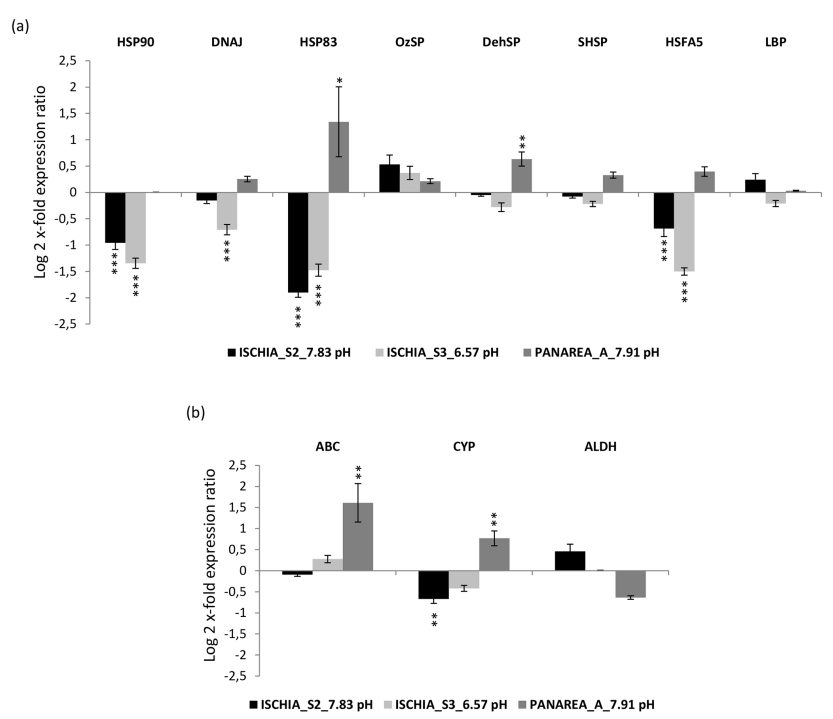

Figure 1. Expression levels of $P$. oceanica heat shock protein (a) and primary metabolism genes (b) from plants collected at Ischia (S2 and S3 sites, with pH 7.83 and 6.57, respectively) in relation to the control site ( $\mathrm{pH} 8.14)$, and at Panarea $(\mathrm{pH} 7.91)$ in relation to its control site ( $\mathrm{pH} 8.17)$.

( $p<0.05$ for Ischia $\mathrm{S} 2, p<0.01$ for Ischia S3 and Panarea), GSH-S did not show significant variations, and GR was down-regulated at both Ischia sites $(p<0.001$ for both) and up-regulated at the Panarea site $(p<0.01)$. Regarding the ascorbate-related enzymes (AR, APX3 and CAPX), AR did not show significant changes, APX3 was only significantly down-regulated at the Ischia S2 site $(p<0.001)$, and CAPX was down-regulated at the Ischia S2 site $(p<0.001)$ and up-regulated at Panarea $(p<0.01)$. Finally, Prx Q was up-

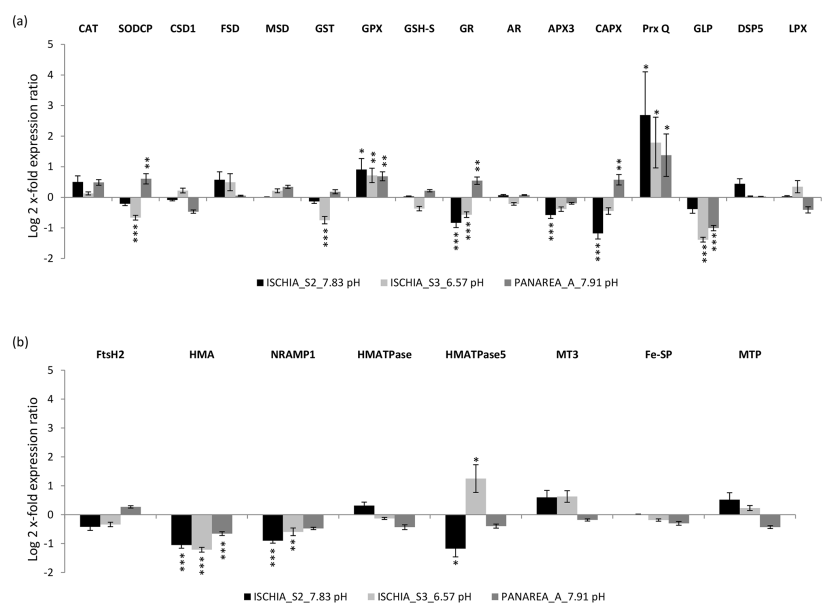

Figure 2. Expression levels of $P$. oceanica antioxidant (a) and heavy-metal-related genes (b) from plants collected at Ischia (S2 and S3 sites with $\mathrm{pH} 7.83$ and 6.57) in relation to the control site ( $\mathrm{pH} 8.14)$, and at Panarea ( $\mathrm{pH} 7.91)$ in relation to its control site $(\mathrm{pH} 8.17)$. Control sites are represented by $x$ axis.

regulated at all the sites $(p<0.05)$, while GLP was downregulated at both the Ischia S3 site and the Panarea site $(p<0.001)$. DSP5 and LPX did not change significantly.

For the metal-related genes (Fig. 2b), HMA was downexpressed at both Ischia and Panarea $(p<0.001)$ and NRAMP1 only at the Ischia sites $(p<0.001$ for S2 and $p<0.01$ for S3), while HMATPase5 was down-regulated at S2 and up-regulated at S3 ( $p<0.05$ for both). The other genes did not change significantly.

\section{Discussion}

To our knowledge, there are no published data on gene expression patterns in seagrasses in the vicinity of submarine volcanic vents. Here we analyzed the expression of 35 genes of the Mediterranean engineering seagrass species Posidonia oceanica, in high- $\mathrm{CO}_{2}$, low-pH sites, in relation to control sites. Genes involved in different phases of plant response to stress were selected. Fifty-one percent of genes analyzed in this study showed significant expression changes at either the two sites of Ischia, at Panarea, or at both locations (summarized in Fig. 2). A consistent gene response at the three sites was observed for three genes - heavy-metal-associated (HMA) domain, glutathione peroxidase (GPX) and peroxiredoxin Q (Prx Q). HMA was significantly down-regulated at both Ischia and Panarea, showing that plants do not increase the synthesis of heavy metal detoxification proteins in proximity to volcanic emissions compared to the control site. This was further supported by the consistent pattern observed at both Ischia and Panarea of the down-regulation of most metal detoxification genes examined, suggesting that the putative heavy metal emissions from the vents at Ischia 
and Panarea do not cause stress on P. oceanica plants. The bioavailability of heavy metals, which depends on $\mathrm{pH}$ and redox potential, may be low at the sites where plants grow, as Vizzini et al. (2013) pointed out for the volcanic vents of the island of Vulcano, Italy.

Glutathione peroxidase (GPX) and Peroxiredoxin Q (Prx Q), involved in free radical detoxification, were significantly up-regulated at both sites in Ischia and Panarea in relation to control sites, suggesting that $P$. oceanica plants are activating similar antioxidant protective mechanisms. Peroxiredoxins are ubiquitous thioredoxin- or glutaredoxin-dependent peroxidases, the function of which is to destroy peroxides (Rouhier et al., 2004), while GPX is important for reducing cytotoxic hydroperoxides (Lubos et al., 2011). In contrast, the activity of another antioxidant gene, the germin-like protein (GLP; Gucciardo et al., 2007), was down-regulated at both sites in Ischia (although in S2, pH 7.83, it was not significant) as well as in Panarea, indicating that this antioxidant defence system was not active in plants at the vicinity of vents.

Many contrasting patterns in the expression of the studied genes were observed between Ischia and Panarea, indicating that different environmental stressors are at play. Fourteen out of the 18 genes exhibiting significant expression changes were different between Panarea and Ischia. Unlike in the control, plants collected in the Panarea acidified site activated antioxidant enzymes such as SODCP, GR, CAPX, and detoxification proteins, such as CYP and ABC. Moreover, and by contrast with the Panarea plants, for the plants collected in the Ischia acidified sites these enzymes were down-expressed or did not show any significant change. Most of these genes are also activated after various types of biotic and abiotic stressors in different plants species (see Vranovà et al., 2002, for a review). Our results indicate that, in contrast with Ischia, P. oceanica at Panarea faces stressors near the vents that result in the production of reactive oxygen species that trigger antioxidant responses. There are only few published studies on the occurrence of antioxidant responses in seagrasses, mostly based on indirect observations of photosynthetic parameters derived from chlorophyll $a$ fluorescence (Ralph et al., 1998; Campbell et al., 2006), and our work is the first one to show the expression of genes associated with the antioxidant responses in P. oceanica.

The activation of heat shock protein genes such as HSP83 and DehSP in Panarea and the significant down-regulation of HSP90, DNAJ, HSP83 and HSFA5 in Ischia plants is also worthy of attention. HSPs play an essential role as molecular chaperones by assisting the correct folding of nascent and stress-accumulated misfolded proteins, and by preventing their aggregation. HSPs' induction and synthesis are not only a response to high temperature, which does not occur in Panarea, but also to many different types of stress, including exposure of cells to toxins or nitrogen deficiency (Santoro, 2000). As HSPs are very sensitive to even minor damage, they are suitable as an early-warning bio-indicator of cellular hazard (Bergmann et al., 2010; Gupta et al., 2010). Our observation that HSPs were down-regulated at Ischia and up-regulated at Panarea supports the overall finding that relevant environmental differences exist between the two volcanic sites. An alternative hypothesis is that $P$. oceanica gene expression responses at Panarea are still going through the initial phase of acclimation, whereas at Ischia the species has already adapted to existing environmental conditions. Thus, the natural gene expression differences revealed in this work may be a component of the species homeostatic evolutionary compensation. The volcanic vent in Ischia could in fact be as old as about 2000 years, as indicated by archaeological evidence (Lombardi et al., 2011), whereas the vent in Panarea is only about 10 years old. It is quite possible that some of the Ischia genotypes of $P$. oceanica have been there since the onset of the volcanic vents as it has been recently revealed that the longevity of this species can be up to thousands of years (Arnaud-Haond et al., 2012).

This is the first time that a gene expression study has been performed in marine plants in the vicinity of submarine volcanic vents, which are generally assumed to be good natural laboratories for investigating the effects of increased $\mathrm{CO}_{2}$ and ocean acidification on marine organisms. In our analysis, we identified a subset of genes that were coherently expressed at both sites and that could be further explored for suggesting their use as early-warning indicators of low$\mathrm{pH}$ conditions in photosynthetic marine organisms. Nevertheless, caution should be taken when using only natural volcanic vents as a proxy for future ocean acidification scenario, and experimental work in controlled laboratory conditions is necessary to unambiguously test organismal response to increased $\mathrm{CO}_{2}$ and low-pH conditions. Our results call for careful consideration of other factors that can cause stress to seagrasses and other organisms near the vents and that may confound the effects of $\mathrm{CO}_{2}$ and acidification. In order to clarify/predict seagrass stress responses to environmental stimuli, the study of general stress-coping, stress-avoiding, and tolerance mechanisms is needed, as is the analysis of more than one gene category.

\section{The Supplement related to this article is available online at doi:10.5194/bg-12-4185-2015-supplement.}

Author contributions. C. Lauritano, J. Silva, R. Santos and G. Procaccini designed the experiments and C. Lauritano, M. Ruocco, E. Dattolo, M. C. Buia, J. Silva, I. Olivé and M. M. Costa carried them out. C. Lauritano prepared the manuscript with contributions from all co-authors, with G. Procaccini and R. Santos as the main contributors. 
Acknowledgements. We are grateful for partial funding for this research from the project HighGrass "High- $\mathrm{CO}_{2}$ effects on seagrass photosynthetic ecophysiology" (PTDC/MAREST/ 3687/2012), to which this paper is a contribution, the MIUR Italian flagship project RITMARE and the ESF COST Action "Seagrass Productivity: from genes to ecosystem management". We also thank Domenico D'Alelio for sampling support, the staff of the Molecular Biology and Bioinformatics Unit, and the staff of Villa Dohrn (Ischia, NA, Italy) of the Stazione Zoologica Anton Dohrn for their support in laboratory experiments and in field work.

Edited by: K. Jardine

\section{References}

Ahuja, I., de Vos, R. C., Bones, A. M., and Hall, R. D.: Plant molecular stress responses face climate change, Trends Plant. Sci., 15, 664-674, 2010.

Alberto, F., Correia, L., Arnaud-Haond, S., Billot, C., Duarte, C. M., and Serrão, E.: New microsatellite markers for the endemic Mediterranean seagrass Posidonia oceanica, Mol. Ecol. Notes, 3, 253-255, 2003.

Alexandre, A., Silva, J., Buapet, P., Bjork, M., and Santos, R.: Effects of $\mathrm{CO}_{2}$ enrichment on photosynthesis, growth, and nitrogen metabolism of the seagrass Zostera noltii, Ecol. Evol., 2, 26202630, 2012.

Andersen, C. L., Jensen, J. L., and Orntoft, T. F.: Normalization of real-time quantitative reverse transcription-PCR data: A modelbased variance estimation approach to identify genes suited for normalization, applied to bladder and colon cancer data sets, Cancer Res., 64, 5245-5250, 2004.

Arnaud-Haond, S., Duarte, C. M., Diaz-Almela, E., Marbà, N., Sintes, T., and Serrão, E.: Implications of Extreme Life Span in Clonal Organisms: Millenary Clones in Meadows of the Threatened Seagrass Posidonia oceanica, PLoS ONE, 7, e30454, doi:10.1371/journal.pone.0030454, 2012.

Arnold, T., Mealey, C., Leahey, H., Miller, A.W., Hall-Spencer, J.M., Milazzo, M., and Maers, K.: Ocean acidification and the loss of phenolic substances in marine plants, PLoS ONE, 7(4), e35107, 2012.

Arranz, S. E., Avarre, J. C., Balasundaram, C., Bouza, C., Calcaterra, N. B., Cezilly, F., Chen, S. L., Cipriani, G., Cruz, V. P., D'Esposito, D., Daniel, C., Dejean, A., Dharaneedharan, S., Díaz, J., Du, M., Durand, J. D., Dziadek, J., Foresti, F., Pengcheng, F., Gao, Q. B., García, G., Gauffre-Autelin, P., Giovino, A., Goswami, M., Guarino, C., Guerra-Varela, J., Gutiérrez, V., Harris, D. J., Heo, M. S., Khan, G., Kim, M., Lakra, W. S., Lauth, J., Leclercq, P., Lee, J., Lee, S. H., Lee, S., Lee, T., Li, Y. H., Liu, H., Liu, S., Malé, P. J., Mandhan, R. P., Martinez, P., Mayer, V. E., Mendel, J., Mendes, N. J., Mendonça, F. F., Minias, A., Minias, P., Oh, K. S., Oliveira, C., Orivel, J., Orsini, L., Pardo, B. G., Perera, A., Procaccini, G., Rato, C., Ríos, N., Scibetta, S., Sharma, B. S., Sierens, T., Singh, A., Terer, T., Triest, L., Urbánková, S., Vera, M., Villanova, G. V., Voglmayr, H., Vyskočilová, M., Wang, H., Wang, J. L., Wattier, R. A., Xing, R., Yadav, K., Yin, G., Yuan, Y., Yun, J. C., Zhang, F. Q., Zhang, J. H., and Zhuang, Z.: Permanent genetic resources added to molecular ecology resources database, Mol. Ecol. Resour., 13, 546-549, 2013.
Bard, S. M.: Multixenobiotic resistance as a cellular defense mechanism in aquatic organisms, Aquat. Toxicol., 48, 357-389, 2000.

Bergmann, N., Winters, G., Rauch, G., Eizaguirre, C., Gu, J., Nelle, P., Fricke, B., and Reusch, T. B. H.: Population-specificity of heat stress gene induction in northern and southern eelgrass Zostera marina populations under simulated global warming, Mol. Ecol., 19, 2870-2883, 2010.

Bidle, K. D. and Bender, S. J.: Iron Starvation and Culture Age Activate Metacaspases and Programmed Cell Death in the Marine Diatom Thalassiosira pseudonana, Eukaryotic Cell, 7, 223-236, 2008.

Campbell, S. J., Kerville, S. P., Coles, R. G., and Short, F.: Photosynthetic responses of subtidal seagrasses to a daily light cycle in Torres Strait: A comparative study, Cont. Shelf Res., 28, 22752281, 2008.

Carter, C. and Thombur, R. W.: Germin-Like Proteins: Structure, Phylogeny, and Function, J. Plant Biol., 42, 97-108, 1999.

Costa, M. M., Barrote, I., Silva, J., Olivé, I., Alexandre, A., Albano, S., and Santos, R.: Epiphytes modulate Posidonia oceanica photosynthetic production, energetic balance, antioxidant mechanisms and oxidative damage, Frontiers in Marine Science, submitted, 2015.

Costanza, R., d'Arge, R., de Groot, R. S. Farberk, S., Grasso, M., Hannon, B., Limburg, K., Naeem, S., O’Neill, R. V., Paruelo, J., Raskin, R. G., Sutton, P., and van den Belt, M.: The value of the world's ecosystem services and natural capital, Nature, 387, 253-260, 1997.

Cullen-Unsworth, L. C., Nordlund, L. M., Paddock, J., Baker, S., McKenzie, L. J., and Unsworth, R. K. F.: Seagrass meadows globally as a coupled social-ecological system: Implications for human wellbeing, Mar. Pollut. Bull., 83, 387-397, 2014.

Dattolo, E., Ruocco, M., Brunet, C., Lorenti, M., Lauritano, C., D' Esposito, D., De Luca, P., Sanges, R., Mazzuca, S., and Procaccini, G.: Response of the seagrass Posidonia oceanica to different light environments: Insights from a combined molecular and photo-physiological study, Mar. Environ. Res., 101, 225-236, 2014.

Evans, T. G. and Watson-Wynn, P.: Effects of Seawater Acidification on Gene Expression: Resolving Broader-Scale Trends in Sea Urchins, The Biological Bulletin, 226, 237-254, 2014.

Evans, T. G., Chan, F., Menge, B. A., and Hofmann, G. E.: Transcriptomic responses to ocean acidification in larval sea urchins from a naturally variable pH environment, Mol. Ecol., 22, 1609$1625,2013$.

de Alteriis, G. and Toscano, F.: Introduzione alla geologia dei mari circostanti le isole Flegree di Ischia, Procida e Vivara, Accademia delle Scienze, Lettere e Arti in Napoli, Memoria della Società di Fisica e Matematica, 5, 3-26, 2003.

Feder, M. E. and Hofmann, G. E.: Heat-shock proteins, molecular chaperones, and the stress response: evolutionary and ecological physiology, Annu. Rev. Physiol., 61, 243-282, 1999.

Fourqurean, J. W., Duarte, C. M., Kennedy, H., Marbà, N., Holmer, M., Mateo, M. A., Apostolaki, E. T., Kendrick, G. A., KrauseJensen, D., McGlathery, K. J., and Serrano, O.: Seagrass ecosystems as a globally significant carbon stock, Nat. Geosci., 5, 505$509,2012$.

Granados-Cifuentes, C., Bellantuono, A. J., Ridgway, T., HoeghGuldberg, O., and Rodriguez-Lanetty, M.: High natural gene expression variation in the reef-building coral Acropora millepora: 
potential for acclimative and adaptive plasticity. BMC Genomics, 14, doi:10.1186/1471-2164-14-228, 2013

Gucciardo, S., Wisniewski, J. P., Brewin, N. J., and Bornemann, S.: A germin-like protein with superoxide dismutase activity in pea nodules with high protein sequence identity to a putative rhicadhesin receptor, J. Exp. Bot., 58, 1161-1171, 2007.

Gupta, S., Deepti, A., Deegan, S., Lisbona, F., Hetz, C., and Samali, A.: HSP72 Protects Cells from ER Stressinduced Apoptosis via Enhancement of IRE1 $\alpha$-XBP1 Signaling through a Physical Interaction, PLoS Biology, 8, e1000410, doi:10.1371/journal.pbio.1000410, 2010.

Hall-Spencer, J. M., Rodolfo-Metalpa, R., Martin, S., Ransome, E., Fine, M., Turner, S. M., Rowley, S. J., Tedesco, D., and Buia, M. C.: Volcanic carbon dioxide vents show ecosystem effects of ocean acidification, Nature, 454, 96-99, 2008.

Harley, C. D. G., Hughes, A. R., Hultgren, K. M., Miner, B. G., Sorte, C. J. B., Thornber, C. S., Rodriguez, L. F., Tomanek, L., and Williams, S. L.: The impacts of climate change in coastal marine systems, Ecol. Lett., 9, 228-241, 2006.

Harms, L., Frickenhaus, S., Schiffer, M., Mark Felix, C., Storch, D., Held, C., Pörtner , H.-O., and Lucassen, M.: Gene expression profiling in gills of the great spider crab Hyas araneus in response to ocean acidification and warming, BMC Genomics, 15, 2014.

Hussain, D., Haydon, M. J., Wang, Y., Wong, E., Sherson S. M., Young, J., Camakaris, J., Harper, J. F., and Cobbett, C. S.: PType atpase heavy metal transporters with roles in essential zinc homeostasis in Arabidopsis, Plant Cell, 16, 1327-1339, 2004.

Italiano, F. and Nuccio, P. M.: Geochemical investigations of submarine volcanic exhalations to the east of Panarea, Aeolian Islands, Italy, J. Volcanol. Geoth. Res., 46, 125-141, 1991.

Jiang, A. Z. J., Huang, X. P., and Zhang, J. P.: Effects of $\mathrm{CO}_{2}$ Enrichment on Photosynthesis, Growth, and Biochemical Composition of Seagrass Thalassia hemprichii (Ehrenb.), J. Integr. Plant Biol., 52, 904-913, 2010.

Kaniewska, P., Campbell, P. R., Kline, D. I., Rodriguez-Lanetty, M., Miller, D. J., Dove, S., and Hoegh-Guldberg, O.: Major Cellular and Physiological Impacts of Ocean Acidification on a Reef Building Coral, PLoS One, 7, e34659, doi:10.1371/journal.pone.0034659, 2012.

Kerrison, P., Hall-Spencer, J. M., Suggett, D. J., Hepburn, L. J., and Steinke, M.: Assessment of $\mathrm{pH}$ variability at a coastal $\mathrm{CO}_{2}$ vent for ocean acidification studies, Estuar. Coast. Shelf S., 94, 129137,2011

Koch, M., Bowes, G., Ross, C., and Zhang, X. H.: Climate change and ocean acidification effects on seagrasses and marine macroalgae, Glob. Change Biol., 19, 103-132, 2013.

Kroeker, K. J., Kordas, R. L., Crim, R. N., and Singh, G. G.: Metaanalysis reveals negative yet variable effects of ocean acidification on marine organisms, Ecol. Lett., 13, 1419-1434, 2010.

Lamkemeyer, P., Laxa, M., Collin, V., Li, W., Finkemeier, I., Schöttler, M. A., Holtkamp, V., Tognetti, V. B., Issakidis-Bourguet, E., Kandlbinder, A., Weis, E., Miginiac-Maslow, M., and Dietz, K. J.: Peroxiredoxin Q of Arabidopsis thaliana is attached to the thylakoids and functions in context of photosynthesis, The Plant Journal, 45, 968-981, 2006.

Lauritano, C., Orefice, I., Procaccini, G., Romano, G., and Ianora, A.: Key Genes as Stress Indicators in the Ubiquitous Diatom Skeletonema marinoi, BMC Genomics, 16, 2015.
Lombardi, C., Gambi, M. C., Vasapollo, C., Taylor, P., and Cocito, S.: Skeletal alterations and polymorphism in a Mediterranean bryozoan at natural $\mathrm{CO}_{2}$ vents, Zoomorphology, 130, 135-145, 2011.

Lubos, E., Loscalzo, J., and Handy, D. E.: Glutathione Peroxidase1 in Health and Disease: From Molecular Mechanisms to Therapeutic Opportunities, Antioxid Redox Signal, 15, 1957-1997, 2011.

Marchitti, S. A., Brocker, C., Stagos, D., and Vasiliou, V.:Non-P450 aldehyde oxidizing enzymes: the aldehyde dehydrogenase superfamily, Drug Metab. Toxicol., 4, 697-720, 2008.

Martin, S., Rodolfo-Metalpa, R., Ransome, E., Rowley, S., Buia, M. C., Gattuso, J. P., and Hall-Spencer, J. M.: Effects of naturally acidified seawater on seagrass calcareous epibionts, Biol. Lett., 4, 689-692, 2008.

Martínez-Crego, B., Olivé, I., and Santos, R.: $\mathrm{CO}_{2}$ and nutrientdriven changes across multiple levels of organization in Zostera noltii ecosystems, Biogeosciences, 11, 7237-7249, doi:10.5194/bg-11-7237-2014, 2014.

Mazzella, L., Buia, M., Gambi, M. C., Lorenti, M., Russo, G. F., Scipione, M. B., and Zupo, V.: Plant-animal trophic relationships in the Posidonia oceanica ecosystem of the Mediterranean Sea, in: Plant-animal interactions in the marine benthos, edited by: John, D. M., Hawkins, S. J., and Price, J. H., Syst. Assoc. Spec., 46, 165-18, 1992.

Mazzuca, S., Björk, M., Beer, S., Felisberto, P., Gobert, S., Procaccini, G., Runcie, J., Silva, J., Borges, A. V., Brunet, C., Buapet, P., Champenois, W., Costa, M. M., D’ Esposito, D., Gullström, M., Lejeune, P., Lepoint, G., Olivé, I., Rasmusson, L. M., Richir, J., Ruocco, M., Serra, I. A., Spadafora, A., and Santos, R.: Establishing research strategies, methodologies and technologies to link genomics and proteomics to seagrass productivity, community metabolism, and ecosystem carbon fluxes, Frontiers in Plant Science, 4, 1e19, doi:10.3389/fpls.2013.00038, 2013.

Mcleod, E., Chmura, G. L., Bouillon, S., Salm, R., Björk, M., Duarte, C. M., Lovelock, C. E., Schlesinger, W. H., and Silliman, B. R.: A blueprint for blue carbon: toward an improved understanding of the role of vegetated coastal habitats in sequestering $\mathrm{CO}_{2}$, Front. Ecol. Environ., 9, 552-560, 2011.

Migliaccio, M., De Martino, F., Silvestre, F., and Procaccini, G.: Meadow-scale genetic structure in Posidonia oceanica. Mar. Ecol-Prog. Ser., 304, 55-65, 2005.

Mittler, R.: Oxidative stress, antioxidants and stress tolerance, Trends Plant Sci., 7, 405-410, 2002.

Mittler, R.: Abiotic stress, the field environment and stress combination, Trends Plant Sci., 11, 15-19, 2006.

Moya, A., Huisman, L., Ball, E. E., Hayward, D. C., Grasso, L. C., Chua, C. M., Woo, H. N., Gattuso, J.-P., Foret, S., and Miller, D. J.: Whole Transcriptome Analysis of the Coral Acropora millepora Reveals Complex Responses to $\mathrm{CO}_{2}$-driven Acidification during the Initiation of Calcification, Mol. Ecol., 21, 2440 2454, 2012.

Moya, A., Huisman, L., Foret, S., Gattuso, J.-P., Hayward, D. C., Ball, E. E., and Miller, D. J.: Rapid acclimation of juvenile corals to CO-mediated acidification by upregulation of heat shock protein and Bcl-2 genes, Mol. Ecol., 24, 438-452, 2015.

Oleksiak, M. F., Churchill, G. A., and Crawford, D. L.: Variation in gene expression within and among natural populations, Nature Gen., 32, 261-266, 2002. 
Orth, R. J., Carruthers, T. J. B., Dennison, W. C., Duarte, C. M., Fourqurean, J. W., Heck Jr., K. L., Hughes, A. R., Kendrick, G. A., Kenworthy, W. J., Olyarnik, S., Short, F. T., Waycott, M., and Willia, S. L.: A global crisis for seagrass ecosystems, Bioscience, 56, 987-996, 2006.

Palacios, S. L. and Zimmerman, R. C.: Response of eelgrass Zostera marina to $\mathrm{CO}_{2}$ enrichment: possible impacts of climate change and potential for remediation of coastal habitats, Mar. Ecol-Prog. Ser., 344, 1-13, 2007.

Pendleton, L., Donato, D. C., Murray, B. C., Crooks, S., Jenkins, W. A., Sifleet, S., Craft, C., Fourqurean, J. W., Kauffman, J. B., Marbà, N., Megonigal, P., Pidgeon, E., Herr, D., Gordon, D., and Baldera, A.: Estimating global "blue carbon" emissions from conversion and degradation of vegetated coastal ecosystems, PLoS ONE, 7, e43542, doi:10.1371/journal.pone.0043542, 2012.

Pergent, G., Bazairi, H., Bianchi, C. N., Boudouresque, C. F., Buia, M. C., Clabaut, P., Harmelin-Vivien, M., Mateo, M. A., Montefalcone, M., Morri, C., Orfanidis, S., Pergent-Martini, C., Semroud, R., Serrano, O., and Verlaque, M.: Mediterranean seagrass meadows: resilience and contribution to climate change mitigation, Gland Switzerland and Malaga, Spain: IUCN, 40 pp., ISBN:978-2-8317-1457-8, 2012.

Pessarakli, M.: Handbook of plant and crop stress, 2nd Edn., Marcel Dekker, Inc. New York, 1198 pp., 2011.

Pfaffl, M. W., Tichopad, A., Prgomet, C., and Neuvians, T. P.: Determination of stable housekeeping genes, differentially regulated target genes and sample integrity: BestKeeper - Excel-based tool using pair-wise correlations, Biotechnol. Lett., 26, 509-515, 2004.

Procaccini, G. and Waycott, M.: Microsatellite loci identified in the seagrass Posidonia oceanica (L.) Delile, J. Hered., 89, 562-568, 1998.

Ralph, P. J.: Photosynthetic response of laboratory-cultured Halophila ovalis to thermal stress, Mar. Ecol-Prog. Ser., 171, 123-130, 1998.

Regoli, F. and Giuliani, M. E.: Oxidative pathways of chemical toxicity and oxidative stress biomarkers in marine organisms, Mar. Environ. Res., 93, 106e117, doi:10.1016/j.marenvres.2013.07.006, 2014.

Ricachenevsky, F. K., Menguer, P. K., Sperotto, R. A., Williams, L. E., and Fett, J. P.: Roles of plant metal tolerance proteins (MTP) in metal storage and potential use in biofortification strategies, Front. Plant Sci., 4, doi:10.3389/fpls.2013.00144, 2013.

Rouhier, N., Gelhaye, E., Gualberto, J. M., Jordy, M. N., De Fay, E., Hirasawa, M., Duplessis, S., Lemaire, S. D., Frey, P., Martin, F., Manieri, W., Knaff, D. B., and Jacquot, J. P.: Poplar Peroxiredoxin Q. A Thioredoxin-Linked Chloroplast Antioxidant Functional in Pathogen Defense, Plant Physiol., 134, 1027-1038, 2004.

Santoro, M. G.: Heat shock factors and the control of the stress response, Biochem. Pharmacol., 59, 55-63, 2000.

Seitz, R. D., Wennhage, H., Bergstrom, U., Lipcius, R. N., and Ysebaert, T.: Ecological value of coastal habitats for commercially and ecologically important species, ICES J. Mar. Sci., 71, 648665,2014
Serra, I. A., Innocenti, A. M., Di Maida, G., Calvo. S., Migliaccio, M., Zambianchi, E., Pizzigalli, C., Arnaud-Haond, S., Duarte, C. M., Serrão, E., and Procaccini, G.; Genetic structure in the Mediterranean seagrass Posidonia oceanica. Disentangling past vicariance events from contemporary patterns of gene flow, Mol. Ecol., 19, 557-568, 2010.

Serra, I. A., Lauritano, C., Dattolo, E., Puoti, A., Nicastro, S., Innocenti, A. M., and Procaccini, G.: Reference genes assessment for the seagrass Posidonia oceanica in different salinity, $\mathrm{pH}$ and light conditions, Mar. Biol., 159, 1269-1282, 2012.

Sorensen, J. G., Kristensen, T. N. and Loeschcke, V.: The evolutionary and ecological role of heat shock proteins, Ecol. Lett., 6, 1025-1037, 2003.

Tassi, F., Capaccioni, B., Caramanna, G., Cinti, D., Montegrossi, G., Pizzino, L., Quattrocchi, F., and Vaselli, O.: Low-pH waters discharging from submarine vents at Panarea Island (Aeolian Islands, southern Italy) after the 2002 gas blast: Origin of hydrothermal fluids and implications for volcanic surveillance, Appl. Geochem., 24, 246-254, 2009.

Thom, R. M.: $\mathrm{CO}_{2}$-enrichment effects on eelgrass (Zostera marina L.) and bull kelp (Nereocystis luetkeana (Mert) P \& R), Water Air Soil Poll., 88, 383-391, 1996.

Tomasello, A., Di Maida, G., Calvo, S., Pirrotta, M., Borra, M., and Procaccini, G.: Seagrass meadows at the extreme of environmental tolerance: the case of Posidonia oceanica in a semi-enclosed coastal lagoon, Mar. Ecol., 30, 288-300, 2009.

Tuba, Z. and Lichtenthaler, H. K.: Long-Term Acclimation of Plants to Elevated $\mathrm{CO}_{2}$ and Its Interaction with Stresses, Ann. NY Acad. Sci., 1113, 135-146, 2007.

Valière, N.: Gimlet: a computer program for analysing genetic individual identification data, Mol. Ecol. Notes, 2, 377-379, 2002.

Vandesompele, J., De Preter, K., Pattyn, F., Poppe, B., Van Roy, N., De Paepe, A., and Speleman F.: Accurate normalization of realtime quantitative RT-PCR data by geometric averaging of multiple internal control genes, Genome Biol., 3, doi:10.1186/gb2002-3-7-research0034, 2002.

Vizzini, S., Di Leonardo, R., Costa, V., Tramati, C. D., Luzzu, F., and Mazzola, A.: Trace element bias in the use of $\mathrm{CO}_{2}$ vents as analogues for low $\mathrm{pH}$ environments: Implications for contamination levels in acidified oceans, Estuar. Coast Shelf S., 134, 19-30, 2013.

Vranová, E., Inzé, D., and Van Breusegem, F.: Signal transduction during oxidative stress, J. Exp. Bot., 53, 1227-1236, 2002.

Whitehead, A. and Crawford, D. L.: Variation within and among species in gene expression: raw material for evolution, Mol. Ecol., 15, 1197-1211, 2006.

Wissler, L., Dattolo, E., Moore, A. D., Reusch, T. B. H., Olsen, J., Migliaccio, M., Bornberg-Bauer, E., and Procaccini, G.: Dr. Zompo: an online data repository for Zostera marina and Posidonia oceanica ESTs, Database: The Journal of Biological Databases and Curation, 2009.

Zucco, C.: Evoluzione urbanistico territoriale delle isole Flegree (Ischia, Procida e Vivara), Procida e Vivara, Accademia delle Scienze, Lettere e Arti in Napoli, Memoria della Società di Fisica e Matematica, 5, 303-396, 2003. 